\title{
FUNCTIONAL FAECAL INCONTINENCE IN CHILDREN
}

\author{
BY \\ IAN BERG* and KEVIN VERNON JONES' \\ From The Hospital for Sick Children, Great Ormond Street, London
}

(RECEIVED FOR PUBLICATION FEBRUARY 4, 1964)

This paper is concerned with faecal incontinence (defined as 'the misplaced passage of faeces') in children, without organic disease that would be sufficient to account for it. To assess current understanding and management of the condition, 78 cases (excluding children with organic disease of the lower bowel or nervous system and those with sub-normal intelligence) were investigated at The Hospital for Sick Children.

The survey led to a clinical classification of the condition according to the presence or absence of (1) a normal bowel habit (defined as the willing use of toilet facilities"), and (2) severe constipation (defined as 'persisting infrequency of defaecation often with difficulty'). The classification revealed five clinical syndromes with distinctive features and also suggested possible causative factors.

We felt that conventional treatment had been too drastic since it involved mechanical emptying of the bowel from below, hospital admission, and formal psychotherapy; and also that it had been too exclusively either physical or psychiatric for a disorder in which mechanical and psychological factors are inextricably combined. So, when the survey of cases managed by others was complete, 59 children with functional faecal incontinence were treated by us (mainly by I.B.) in paediatric outpatient departments, using only oral laxatives and simple psychiatric techniques.

With regard to terminology, 'functional faecal incontinence' and 'soiling' are used interchangeably for the condition studied, and diagnostic labels such as colonic inertia, encopresis, psychogenic megacolon, and overflow incontinence, associated with particular aetiological theories and methods of treatment, are avoided.

Most children are toilet trained by 2 years of age (Isaacs, 1936; Gesell and Thompson, 1938; Mac-

- At present Senior Registrar, Department of Psychological Medicine. Royal Hospital for Sick Children, Edinburgh. This work forms part of an M.D. thesis submitted to the University of Leeds.

+ Paediatrician, British Military Hospital, Iserlohn, Germany, B.F.P.O. 24.
Farlane, Allen, and Honzig, 1954; Douglas and Blomfield, 1958), though there is considerable variation between cultures (Halliday, 1946; Roberts and Schoellkopf, 1951; Whiting and Child, 1953; Whiting, 1956: Brazelton, 1962). Functional faecal incontinence was deemed to be present if soiling persisted after the second birthday.

\section{Historical Review}

The earliest description of functional faecal incontinence that we have been able to find is in Henoch's Lectures on Children's Diseases: 1882 (Henoch, 1889). This was followed by a series of case reports at the end of the last century (Fowler, 1882: Wallace, 1888; Mendenhall, 1890; Schilling, 1891; Smith, 1896; Holt, 1897; Rivière, 1898; Buckingham, 1898; Andreyeff, 1898; Comby, 1899; Griffith, 1899; Rotch, 1901).

The first attempt at classification was Ostheimer's (1905). Most classifications have been based on associated enuresis, constipation, or megacolon; on continuity with the normal incontinence of infancy; on bowel habit or on personality type (Thorling, 1923; Jekelius, 1936; Anthony, 1957; Easson, 1960).

Aetiological theories have been generally either psychological or physical and not commonly a mixture of the two. The earliest writers often attributed faecal incontinence to psychological factors (Fowler, 1882; Weissenberg, 1926). Later Freud (1959) explained it by emotional disturbance, Kanner (1935) by toilet training inadequacy, Shirley (1938) by general environmental stress, and Huschka (1942) by coercive training. On the physical side, functional faecal incontinence has been attributed to associated constipation, since Wallace (1888) noted the presence of rectal distension with faeces in a case of soiling. It is now generally accepted that this rectal impaction can interfere mechanically with defaecation (Bloch, 1932; Priesel and Siegl, 1936; Hungerland, 1936) leading to soiling that has been likened to overflow incontinence of urine by Thorling (1923). Constipation from any cause can be 
TABLE 1

CLASSIFICATION OF 78 CASES OF FUNCTIONAL FAECAL INCONTINENCE (FFI)

\begin{tabular}{|c|c|c|c|}
\hline Group & Classification & Severe Constipation & Normal Bowel Habit \\
\hline 1 (16 cases $)$ & Training problems without severe constipaticn & Absent & Absent \\
\hline 2 (16 cases) & Pot refusal retention syndrome & Present & Absent \\
\hline 3 (16 cases $)$ & Severe constipation with overflow & Present & Present \\
\hline $\begin{array}{l}4 \text { ( } 30 \text { cases) } \\
\text { Sub-groups: }\end{array}$ & $\begin{array}{l}\text { Uncomplicated FFI } \\
\text { (a) Stress FFI (10 cases) } \\
\text { (b) Distraction precipitancy FFI ( } 14 \text { cases) } \\
\text { (c) Unclassified (6 cases) }\end{array}$ & Absent & Present \\
\hline
\end{tabular}

exacerbated by fever, anal fissure, or "bad habits, resulting in a megacolon and overflow soiling (Bodian, 1952). The term colonic inertia, which implies a weakened gut wall, has been used to describe this state of affairs (Browne, 1961). Coekin and Gairdner (1960) believed that colonic inertia had a constitutional basis since it sometimes occurs in infancy (Priesel and Siegl, 1936). Psychological theories have been generally employed to explain faecal incontinence without constipation and mechanical theories have been used to account for faecal incontinence with constipation, but Richmond, Eddy, and Garrard (1954) put forward a psychological hypothesis in which the combination of megacolon and soiling was attributed to resistive behaviour. The syndrome was called 'psychogenic megacolon'. Conversely functional faecal incontinence without constipation was considered by Thorling (1923) to be a disorder of rectal innervation.

Management has reflected aetiological views. Where a psychological basis was considered to be the cause, Henoch (1889) obtained relief by injections of placebos, Fowler (1882) removed environmental factors causing emotional distress, and Goodhardt (1902) said, 'treatment should be moral rather than physical. Psychotherapy and other psychiatric treatments have been extensively used (Lehman, 1944).

Those with physical views of causation emptied the gut with laxatives, enemas, suppositories, washouts, and manual removals (Wallace, 1888; Hungerland, 1936; Bodian, Stephens, and Ward, 1949). Prolonged courses of washouts were given to allow the bowel wall to recover its tone (Nixon, 1961). Toilet training was also recommended and follow-up was stressed (MacGregor, 1961).

The tendency for either physical or psychiatric management is typified by Coekin and Gairdner's (1960) paper. Others have been less exclusive and Mac Keith (1960) called for more joint work by psychiatrists and paediatricians in this condition.

\section{Subjects and Methods}

Review Series. 78 cases were reviewed: 38 of these had recently been treated by physicians of the hospital, and the remaining $\mathbf{4 0}$ cases were collected using past hospital records. Parents of children treated for functional faecal incontinence in the previous ten years were written to requesting an interview, and $\mathbf{4 0}$ (about one-third) of these responded.

A history was taken from the parents and the child was examined in each case.

Treatment Series. We then proceeded to treat 59 cases. Of these, 20 were from the 32 in the review serie's that were still soiling. They were selected by their availability for treatment. Colleagues referred to us a further 39 without themselves treating them, but we found that they had, in fact, been given so much treatment at an earlier stage that they were indistinguishable as a group from the other 20 .

\section{Results}

Review Series. Boys predominated over girls $(1 \cdot 6: 1): 60^{\circ}$ of cases had already stopped soiling when we saw them, and their mean age when they ceased, i.e. $7 \cdot 3$ years (S.D. $=2 \cdot 9$ ), was significantly different from the mean age of those still incontinent (mean age 6.6 years, S.D. $=3 \cdot 5 ; \mathrm{t}=3 \cdot 0 ; \mathrm{p}<0.01$ ). The age range was 2-16 years.

Classification (Table 1). It was generally easy to assign the children to one of four groups, from the history.

Group 1: Training problems without severe constipation. This group consisted of children who did not use normal toilet facilities for defaecation. Unlike the group described by Anthony (1957) as "continuous' these children were often from both materially and emotionally good homes.

Group 2: Pot refusal retention syndrome. These children were likewise unwilling to use the toilet, and in addition they tenaciously retained their motions so that gross abdominal and rectal faecal masses were present. They were involved in a struggle with their parents who tried to force them to use the toilet and 
TABLE 2

COMPARISON OF CLASSIFICATION OF FUNCTIONAL FAECAL INCONTINENCE AND PREVIOUS CLASSIFICATIONS

\begin{tabular}{|c|c|}
\hline Present Classification & Approximate Corresponding Category in Literature \\
\hline $\begin{array}{l}\text { Group } 1 \text { : training problems without severe constipation } \\
\text { Group 2: pot refusal retention syndrome } \\
\text { Group 3:* progressive constipation with overflow } \\
\text { Group 4: uncomplicated faecal incontinence } \\
\text { Stress faecal incontinence } \\
\text { Distraction-precipitancy sub-group }\end{array}$ & $\begin{array}{l}\text { Primary infantile encopresis (Easson. 1960) } \\
\text { Psychogenic megacolon (Richmond et al.. 1954) } \\
\text { Psychogenic megacolon (Pinkerton. 1958) } \\
\text { Encopresis (Weissenberg. 1926). Discontinuous encopresis (Anthony. 1957) } \\
\text { Described by Anthony (1957) } \\
\text { Distraction incontinence (Thorling, 1923) }\end{array}$ \\
\hline
\end{tabular}

- The following equivalents for Groups 2 and 3 combined have been used:- constipation incontinence (Thorling. 1923); obstipatio paradoxa (Jekelius. 1936); colonic inertia (Browne, 1961); overflow incontinence (Hartsilver, 1935); terminal reservoir syndrome (Bodian, 1952); rectal inertia (Nixon. 1961): constipation with faecal incontinence (MacGregor, 1961); mechanical faecal incontinence (Coekin and Gairdner. 1960).

punished them for soiling. This is the syndrome that Richmond et al. (1954) called 'psychogenic megacolon'.

Group 3: Progressive (or severe) constipation with overflow. These children had chronic constipation with variable soiling. They attempted to use the toilet, and the faecal incontinence was attributed to a mechanical interference with defaecation.

Group 4: Uncomplicated functional faecal incontinence. There was a normal bowel habit and no severe constipation. We gave the name stress functional faecal incontinence to a sub-group in which the soiling occurred in direct relation to a psychiatric disorder. The remainder showed a number of similar features, including a tendency to soil when distracted in play and a complaint of not being able to reach the toilet in time. The children with these features were included in a sub-group called distraction precipitancy functional faecal incontinence. Thorling (1923) was the first to describe it in detail. A few cases in Group 4 were left unclassified.

Alternative Classifications. Other possible means of classification would not have revealed these five clinical syndromes, previously only suggested or described in isolation (Table 2). Various clinical features of the review series will be discussed to show that they were unsuitable for classification purposes. Group 4 will be considered as a whole.

(i) Continuity with the Training Period (Table 3). This was significantly more common in Group 1 compared with the remainder $\left(\chi^{2}=8 \cdot 17 ; \mathrm{p}<0 \cdot 01\right)$. Late onset of soiling was obviously almost confined to Group 4. Continuity was of little help in classifying severely constipated cases; it also failed to differentiate the psychiatrically disturbed children in Group 4. We did not feel justified in assuming that all cases of discontinuous soiling had emotional disturbance, as did Anthony (1957).

(ii) Enuresis (Table 4). This was only recorded when present at 5 years of age or later. If there was at least three months' freedom previously it was called 'onset'. There was a significantly higher incidence $\left(\chi^{2}=5 \cdot 54, p<0.02\right)$ in Group 4 than in the remainder. The use of enuresis for classification would have cut right across the grouping we adopted. 'Onset enuresis' was almost confined to Group 4.

(iii) Constipation (Table 5) of a degree insufficient for placing the case in Groups 2 and 3 was present in one-third of Groups 1 and 4 respectively.

(iv) Rectal Examination. This was considered positive when more than a small amount of faeces was present. (Estimations of the degree of hardness of the faeces were found to be unreliable.) This sign

TABLE 3

CONTINUITY WITH TRAINING PERIOD

\begin{tabular}{|c|c|c|c|c|c|}
\hline \multirow[b]{2}{*}{ Group } & \multirow[b]{2}{*}{ Classification } & \multirow{2}{*}{\multicolumn{2}{|c|}{ Bowel Habit }} & \multicolumn{2}{|c|}{ Number of Cases } \\
\hline & & & & Continuity & $\begin{array}{l}\text { Late Onset } \\
5 \text { years or } \\
\text { Later }\end{array}$ \\
\hline 1 (16 cases & Training problems without severe constipation & & No normal bowel habit & 14 & $\mathbf{0}$ \\
\hline 2 (16 cases) & Pot refusal retention syndrome & & $\begin{array}{l}\text { No normal bowel habit, } \\
\text { severe constipation }\end{array}$ & 10 & 0 \\
\hline 3 (16 cases) & Progressive constipation with overflow & & Severe constipation & 8 & 4 \\
\hline $\begin{array}{l}4 \text { ( } 30 \text { cases) } \\
\text { Sub-groups: }\end{array}$ & $\begin{array}{l}\text { Uncomplicated FFI } \\
\text { (a) Stress FFI } \\
\text { (b) Distraction precipitancy FFI }\end{array}$ & 1 & & $\begin{array}{l}9 \\
2 \\
7\end{array}$ & $\begin{array}{r}14 \\
7 \\
3\end{array}$ \\
\hline
\end{tabular}


TABLE 4

ENURESIS

\begin{tabular}{|c|c|c|c|c|c|c|}
\hline Group & Classification & Bowel Habit & $\begin{array}{l}\text { No. of } \\
\text { Children } \\
\text { of } 5 \text { years } \\
\text { or over }\end{array}$ & $\begin{array}{c}\text { Continuous } \\
\text { Nocturnal } \\
\text { Enuresis }\end{array}$ & $\begin{array}{l}\text { Continuous } \\
\text { Nocturnal } \\
\text { and Diurnal } \\
\text { Enuresis }\end{array}$ & $\begin{array}{l}\text { Onset } \\
\text { Enuresis }\end{array}$ \\
\hline 1 (16 cases) & $\begin{array}{l}\text { Training problems without } \\
\text { severe constipation }\end{array}$ & No normal bowel habit & 9 & 1 & 4 & 0 \\
\hline 2 (16 cases) & $\begin{array}{l}\text { Pot refusal retention } \\
\text { syndrome }\end{array}$ & $\begin{array}{l}\text { No normal bowel habit, } \\
\text { severe constipation }\end{array}$ & 12 & 1 & 2 & 1 \\
\hline 3 (16 cases) & $\begin{array}{l}\text { Progressive constipation } \\
\text { with overflow }\end{array}$ & Severe constipation & 10 & $\mathbf{0}$ & 1 & 0 \\
\hline $\begin{array}{l}4 \text { ( } 30 \text { cases) } \\
\text { Sub-groups: }\end{array}$ & $\begin{array}{l}\text { Uncomplicated FFI } \\
\text { (a) Stress FFI } \\
\text { (b) Distraction } \\
\text { precipitancy FFI }\end{array}$ & & $\begin{array}{r}27 \\
9 \\
13\end{array}$ & $\begin{array}{l}5 \\
0 \\
4\end{array}$ & $\begin{array}{l}5 \\
1 \\
2\end{array}$ & $\begin{array}{l}8 \\
3 \\
4\end{array}$ \\
\hline
\end{tabular}

TABLE 5

CONSTIPATION (ANY DEGREE OF SEVERITY)

\begin{tabular}{|c|c|c|c|c|c|c|c|c|}
\hline \multirow{2}{*}{ Group No. } & \multirow{2}{*}{ Classification } & \multirow{2}{*}{ Bowel Habit } & \multicolumn{2}{|c|}{ In Infancy } & \multirow{2}{*}{$\begin{array}{l}\text { Consti- } \\
\text { pation } \\
\text { Since } \\
\text { Infancy }\end{array}$} & \multirow{2}{*}{$\begin{array}{l}\text { Late } \\
\text { Onset of } \\
\text { Consti- } \\
\text { pation }\end{array}$} & \multirow{2}{*}{$\begin{array}{l}\text { Holding } \\
\text { Back }\end{array}$} & \multirow{2}{*}{$\begin{array}{l}\text { Extreme } \\
\text { Pot } \\
\text { Refusal }\end{array}$} \\
\hline & & & $\begin{array}{l}\text { Consti- } \\
\text { pation }\end{array}$ & Diarrhoea & & & & \\
\hline 1 (16 cases) & $\begin{array}{l}\text { Training problems without } \\
\text { severe constipation }\end{array}$ & $\begin{array}{l}\text { No normal } \\
\text { bowel habit }\end{array}$ & 0 & 6 & 6 & 4 & 1 & 0 \\
\hline 2 (16 cases) & $\begin{array}{l}\text { Pot refusal retention } \\
\text { syndrome }\end{array}$ & $\begin{array}{c}\text { No normal } \\
\text { bowel habit, } \\
\text { severe constipation }\end{array}$ & 3 & 1 & 16 & 0 & 13 & 11 \\
\hline 3 (16 cases) & $\begin{array}{l}\text { Progressive constipation } \\
\text { with overflow }\end{array}$ & Severe constipation & 11 & 3 & 16 & 0 & 2 & 1 \\
\hline \multirow[t]{2}{*}{$\begin{array}{l}4 \text { ( } 30 \text { cases }) \\
\text { Sub-groups: }\end{array}$} & \multirow{2}{*}{$\begin{array}{l}\text { Uncomplicated FFI (total) } \\
\text { (a) Stress FFI } \\
\text { (b) Distraction } \\
\text { precipitancy FFI }\end{array}$} & & 5 & $\begin{array}{l}6 \\
2\end{array}$ & $\begin{array}{l}9 \\
1\end{array}$ & $\begin{array}{l}1 \\
0\end{array}$ & $\begin{array}{l}\mathbf{0} \\
\mathbf{0}\end{array}$ & $\begin{array}{l}\mathbf{0} \\
\mathbf{0}\end{array}$ \\
\hline & & & 4 & 3 & 7 & 1 & 0 & 0 \\
\hline
\end{tabular}

was positive in almost all the severely constipated soilers in Groups 2 and 3, when they were still soiling, in half of Group 1, and one-third of Group 4. It was, therefore, useless as a means of differentiating our four groups. A positive finding was related to some degree of faecal retention and was more likely to be elicited when there had not been a recent bowel action. (v) Psychological Factors (Table 6) were in fact used to sub-divide the Group 4 in our classification. Three indices were used to assess psychological factors:

Overt Aggression of the mother in toilet training or in response to the symptom was assessed as 'excessive" or 'minimal'. There was a significantly higher incidence of excessive aggression in the mothers of

TABLE 6

PSYCHOLOGICAL FACTORS

\begin{tabular}{|c|c|c|c|c|c|c|c|c|}
\hline \multirow[t]{2}{*}{ Group No. } & \multicolumn{2}{|c|}{$\begin{array}{l}\text { Maternal Coercion in } \\
\text { Toilet Training and } \\
\text { Aggression in } \\
\text { Response to Symptom }\end{array}$} & \multicolumn{2}{|c|}{$\begin{array}{l}\text { Emotional Quality } \\
\text { of Home }\end{array}$} & \multicolumn{2}{|c|}{$\begin{array}{l}\text { General Behavioural } \\
\text { Disturbance of Child }\end{array}$} & \multirow{2}{*}{\multicolumn{2}{|c|}{ Mother's Personality }} \\
\hline & Minimal & Excessive & Poor & Good & Mild & Severe & & \\
\hline 1 (16 cases) & 10 & $\mathbf{0}$ & 2 & 8 & 6 & 3 & ' & Tolerant \\
\hline 2 (16 cases) & 2 & 11 & 6 & 4 & 3 & 8 & & Intolerant; overtly aggressive \\
\hline 3 (16 cases) & $\mathbf{0}$ & 6 & $\mathbf{0}$ & 1 & 7 & $\mathbf{0}$ & & Over-anxious bowel centred \\
\hline \multirow{3}{*}{$\begin{array}{l}4 \text { ( } 30 \text { cases) total } \\
\text { Sub-groups: } \\
\text { (a) Stress } \\
\text { (b) Distraction precipitancy }\end{array}$} & 2 & 12 & 8 & 8 & 11 & 10 & \multicolumn{2}{|c|}{$\begin{array}{l}\text { Psychiatric illness to } \\
\text { greater/lesser degree }\end{array}$} \\
\hline & $\mathbf{0}$ & 10 & 6 & $\mathbf{0}$ & 5 & 5 & l & \\
\hline & 2 & 2 & 2 & 5 & 6 & 4 & 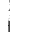 & \\
\hline
\end{tabular}


children in Group 2 compared to the remainder $\left(\chi^{2}=69 \cdot 7, \mathrm{p}<0.001\right)$, and a significantly lower incidence in Group $1\left(\chi^{2}=23 \cdot 45 ; \mathrm{p}<0.001\right)$.

Quality of home was considered 'usually poor' when there was psychiatric illness in parents, a broken home, or excessive tension in the family. Subtle degrees were not considered. Conversely, remarkably sensible and affectionate parents, as well as emotionally excellent homes, were called 'unusually good.

Disturbance in the child was called 'severe' when there was a behaviour disorder gross enough to require psychotherapy. 'Mild' disturbance was recorded when parents sought help for it. 'Severe' disturbance was significantly higher in Groups 2 and 4 combined than in the remainder $\left(\chi^{2}=7 \cdot 0: p<\right.$ $0 \cdot 01)$.

ConClusion. We came to the conclusion that our classification was an improvement on previous ones based on continuity, enuresis, unqualified constipation, faecal distension of the rectum, and psychiatric factors, as it seemed to fit the clinical material more naturally.

Aetiology. The classification used also proved useful in helping us to understand aetiology.

Group 1 was characterized by placid children from secure homes who failed to establish a normal bowel habit, or lost it early on. In over half the cases diarrhoea or hospital admission appeared to interfere with the process of toilet training. Sometimes constipation developed after years of daily soiling. This was interpreted as follows: these children were embarrassed by motions emerging in public, and so retained them temporarily. They often soiled in the evening, after school, or in bed at night. Our classification thus emphasizes that the primary disorder in Group 1 was one of not using the toilet.

In Group 2 there was an active refusal of the child to use the pot, with tenacious retention of faeces. There was a negativistic behaviour disorder in the child and punitive parental attitudes. The tendency for the child to 'hold back' the bowel motions with crossing of the legs and to refuse to sit on the pot, 'going stiff' if forced, was almost confined to this group (Table 5). Retention of urine occurred in 3 cases. It seemed that, at least in the early stages, the absent bowel habit and severe constipation were probably due to psychiatric disturbance.

In the first two groups constipation, mild or severe, was related to some extent to compensation for an absent bowel habit. However, in Group 3 the children had constipation from early infancy
(Table 5), suggesting an underlying physiological disorder, and they willingly used the toilet. Nevertheless, psychological factors were probably important in some cases, since there was a great deal of over-concern about bowel functioning in these families.

There was a similar incidence of fissure, fever, and maternal separation aggravating the constipation in the severely constipated Groups 2 and 3 . Whatever the cause of the severe constipation it was exacerbated by these factors.

Group 4 includes stress functional faecal incontinence in which there appears to be a causal relation between emotional stress and soiling.

There was no obvious cause for the distraction precipitancy sub-group. Thorling (1923) attributed it to a physiological disorder and Jekelius (1936) to a psychological one. There appears to be an instability of continence, intensified by emotional stress. The tendency to mild constipation, which alternated with the incontinence, may have developed as a protection against precipitous defaecation.

Management. As a general rule, we found that the condition had been managed exclusively as either a mechanical or a psychiatric problem. Children with abdominal and rectal faecal masses (in all our four groups) had usually been given courses of colonic washouts and had commonly been admitted to hospital for them. Relapses after a few days or weeks of improvement were frequent, necessitating further treatment of the same sort. Laxatives and suppositories were liberally used in all groups over long periods. Out-patient attendances were surprisingly infrequent and often spread over years.

Formal psychotherapy had been used early in treatment in about one-third of Groups 1 and 4 respectively and after the failure of mechanical methods in about half of Group 2.

A remission was defined as six months of freedom from symptoms. The remission rate in the severely constipated Groups 2 and 3 combined was $47^{\circ}{ }_{0}$. It could not be shown that either hospital admission, washouts, or formal psychotherapy significantly influenced remission in the series as a whole (Tables $7 \mathrm{~A}$, B, and C).

It was a clinical impression that much mechanical treatment and repeated hospital admissions had a deleterious effect on the morale of the children and their families.

Treatment Series. In the 59 children managed by us in the paediatric out-patient department, there were more boys than girls (ratio 1.8 to 1 ), the mean age was 6 years and the range $2 \frac{1}{2}$ to 12 years. The criterion 
TABLE 7A

REVIEW SERIES-PREVIOUS TREATMENT WITH HOSPITAL ADMISSION

\begin{tabular}{|c|c|c|c|}
\hline & Admitted & $\begin{array}{c}\text { Not } \\
\text { Admitted }\end{array}$ & Total \\
\hline $\begin{array}{l}\text { Soiling still present } \\
\text { Soiling not still present } \\
\text { Total }\end{array}$ & $\begin{array}{l}13 \\
24 \\
37\end{array}$ & $\begin{array}{l}19 \\
22 \\
41\end{array}$ & $\begin{array}{l}32 \\
46 \\
78\end{array}$ \\
\hline
\end{tabular}

$x^{2}=0 \cdot 2 . \quad P<0 \cdot 6$. Using Yates' Correction for small numbersno significant difference.

TABLE 7B

REVIEW SERIES-PREVIOUS TREATMENT WITH BOWEL WASHOUTS

\begin{tabular}{|c|c|c|c|c|c|}
\hline & & & $\begin{array}{l}\text { Soiling } \\
\text { Still } \\
\text { Present }\end{array}$ & $\begin{array}{l}\text { Soiling } \\
\text { Not Still } \\
\text { Present }\end{array}$ & Total \\
\hline $\begin{array}{l}\text { Washouts } \\
\text { None } \\
\text { Total } \quad \ldots\end{array}$ & $\begin{array}{l}\cdots \\
\cdots \\
\cdots\end{array}$ & $\cdots$ & $\begin{array}{l}16 \\
16 \\
32\end{array}$ & $\begin{array}{l}23 \\
23 \\
46\end{array}$ & $\begin{array}{l}39 \\
39 \\
78\end{array}$ \\
\hline
\end{tabular}

No difference.

TABLE 7C

REVIEW SERIES-PREVIOUS TREATMENT WITH PSYCHOTHERAPY

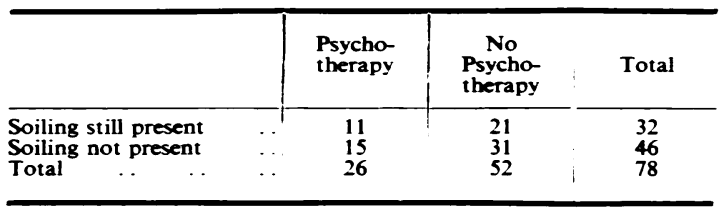

No significant difference.

of remission was the same as in the review series, i.e. 6 months of freedom from symptoms. Treatment was continued for a year before accepting failure, though a small number of cases dropped out before this.

Group 1: Training problems without severe constipation. There were 10 cases ( 6 male 4 female; mean age 6 years; range 3-10 years), of which 4 were from the review series.

After the initial interview it was suggested that each child should attend regularly to discuss why he did not use the toilet. Two were given oral laxatives for associated mild constipation.

The results among these 10 cases were surprisingly good: 7 remissions occurred suddenly after only one or two visits. An eighth remission occurred after three months. We felt that when a family became sufficiently concerned to seek advice about their offspring's reluctance to use the toilet, the child began to co-operate in this respect on its own initiative.

Group 2: Pot refusal retention syndrome. There were 19 cases (13 male 6 female; mean age 5 years; range $2 \frac{1}{2}-10$ years), of which 4 were from the review series. Three cases began with fissure. Previous treatment by others had involved oral laxatives in 19 , mechanical emptying of the gut from below in 10 , and hospital admission in 6.

Our management consisted of frequent (weekly or fortnightly as a general rule) out-patient interviews with parents and child to reduce tension at home and stop punishment for soiling. Oral laxatives were recommended to soften the motions and increase the urge to defaecate. We found senna (Senokot tablets) helpful. Large doses were often necessary initially to relieve the distension, e.g. 6 tablets a day in a 6-year-old child. When the motions began to emerge in the newly-permissive home atmosphere, the child usually began to use the toilet, but it often took some weeks to acquire a normal bowel habit. A maintenance dose of laxative was continued for several months and adjusted by the mother to keep the motions emerging daily. In this group of 19 there were 17 remissions, obtained on average after 3 months of treatment (range 3 weeks to 1 year).

Group 3: Severe constipation with overflow: There were 19 cases $(11$ male 8 female; mean age 6 years; range 3-9 years), of which 7 were from the review series.

In 3, soiling and constipation began after kaolin treatment for gastro-enteritis. Previous treatment by others had involved oral laxatives in 12 , mechanical emptying of the gut from below in 7, and hospital admission in 6.

Our method of management was similar to that used in Group 2, in that oral laxatives were employed initially to evacuate the bowels and later to maintain daily motions, but since the children willingly used the toilet, the frequent out-patient interviews were mainly concerned with reducing worries about constipation and the supposed harmfulness of laxatives.

In this group of 19 cases there were 16 remissions. The average duration of treatment was only three weeks (range 1 week to 6 months).

Group 4: Uncomplicated functional faecal incontinence. (a) Stress sub-group. These cases were not included in the treatment series because the soiling and onset-enuresis seemed to be causally connected with the child's severe emotional disturbance, and the children were, therefore, referred for formal psychiatric management.

(b) Distraction-precipitancy sub-group. There were 11 cases $(8$ male 3 female; mean age 6 years; range 21-12 years), of which 5 were from the review series. The 6 others had the same features that we had found to occur in this sub-group. There was enuresis in 9 cases ( 2 with 'onset-enuresis').

We saw the families frequently to reduce the 
emotional tension created by soiling and to assist them with any interpersonal problems.

Amongst this group of 11 cases there was only one remission, despite a considerable general improvement in emotional well-being. It was difficult to escape the conclusion that these children had a physiological disorder of the bowel.

\section{Discussion}

We felt that the 78 children with functional faecal incontinence that we reviewed had been managed too exclusively as mechanical or psychiatric problems, with insufficient attention to the requirements of the individual child.

Our classification produced five syndromes requiring separate consideration with regard to aetiology, management, and prognosis. The 59 cases we treated confirmed its value.

The Group 1 training problems without severe constipation were due to a failure of development of a normal bowel habit. They responded rapidly to out-patient management.

The Group 4 stress sub-group cases were not included in the treatment series as they were referred for child guidance therapy.

The Group 4 distraction-precipitancy sub-group cuses responded poorly to out-patient management. This sub-group presents a tough problem for future research.

We obtained our most impressive results in the severely constipated soilers (Groups 2 and 3 ). Severe faecal retention was eliminated by oral laxatives and liberal reassurance. It was quite remarkable how large rectal masses were dispersed without mechanical removal from below. Pinkerton (1958) found the same.

When massive faecal retention had been eliminated, the Group 2 (pot refusal retention syndrome) children usually began to co-operate in using the pot. This appeared to be due partly to their own initiative in eliminating the retained masses, and partly to the increased permissiveness at home created by psychiatric work with the parents. The physician's tolerance of the parent's attitudes was a model for the parent to emulate in accepting the child's poor co-operation.

The effect of laxatives in the Group 3 (severe constipation with overflow) cases was also facilitated by a general relief of anxiety in the family. We did not agree with Pinkerton (1958) that using laxatives hindered the psychiatric aspects of treatment. Coekin and Gairdner's (1960) finding that parental co-operation in using oral laxatives is important in maintaining frequent soft motions was confirmed. One advantage of our management was the avoid- ance of unpleasant and possibly harmful procedures such as hospital admission and washouts.

The high remission rate, 33 out of $38\left(87_{\%}^{\circ}\right)$, in the severely constipated soilers (Groups 2 and 3 combined) supports our view that the routine management of these cases should be oral laxatives and simple psychological treatment in paediatric out-patient departments without washouts, hospital admission, or formal psychotherapy.

\section{Summary}

78 children with functional faecal incontinence treated by others were reviewed. A useful classification for aetiology, management, and prognosis emerged. Previously, management had been unsatisfactory, as the problem was looked at as either mechanical or psychiatric.

59 children were treated personally using a combined paediatric/psychiatric approach, and the results supported the value of our classification and method of management.

Possibly harmful procedures, such as hospital admission and mechanical means of emptying the bowel from below, were avoided even in the severely constipated soilers, yet an $87^{\circ}$ o remission rate was obtained in 38 of these children, compared with a $47^{\circ}$ o remission rate in 32 cases treated by conventional means.

It is concluded that the treatment of choice in most cases of functional faecal incontinence is paediatric out-patient management using simple psychiatric methods and oral laxatives as required.

We wish to acknowledge the abundant help we received from all our colleagues. We are grateful to the consultants of the Hospital who generously allowed us to interview and treat their patients. We are particularly indebted to Dr. Mildred Creak, Dr. A. Norman, Professor Sir Alan Moncrieff, Dr. R. Bonham Carter, Mr. H. Nixon, Dr. G. Newns, and Dr. B. Schlesinger who were so helpful in discussing this work with us.

Professor M. Hamilton of Leeds and Dr. C. Hindley of London University kindly advised us on statistics.

\section{REFERENCES}

Andreyeff. A. (1898). Faecal incontinence in a boy 12 years old Dietsk. Med., 3, 271.

Anthony. E. J. (1957). An experimental approach to the psychopathology of childhood: encopresis. Brit. J. med. Psychol., 30. 146.

Bloch, C. E. (1932). Constipation incontinence. Acta med. scand., 78, 248.

Bodian, M. (1952). Chronic constipation in children. Practitioner, $169,517$.

, Stephens, F. D., and Ward, B. C. H. (1949). Hirschsprung's disease and idiopathic megacolon. Lancet. 1, 6.

Brazelton, T. B. (1962). A child-oriented approach to toilet training. Pediatrics, 29, 121.

Browne, D. (1961). In Discussion on megacolon and megarectum. Proc. roy. Soc. Med., 54, 1055.

Buckingham, E. M. (1898). In An American Textbook of the Diseases of Children, 2nd ed., ed. L. Starr. p. 996 . Saunders, Philadelphia. 
Coekin. M., and Gairdner. D. (1960). Faecal incontinence in children: the physical factor. Brit. med. J., 2, 1175, and 1807.

Comby, J. (1899). Traité des Maladies de I'Enfance, 3rd ed., pp. 424-435. Rueff, Paris.

Douglas. J. W. B., and Blomfield. J. M. (1958). Children Under Five, pp. 127-132. Allen and Unwin, London.

Easson. W. M. (1960). Encopresis-psychogenic soiling. Canad. med. Ass. J., 82, 624.

Fowler, G. B. (1882). Incontinence of feces in children. Amer. J. Obstet. Dis. Wom., 15, 984.

Freud, S. (1959). From the history of an infantile neurosis (1918). In Collected Papers, translated by J. and A. Strachey, vol. 3, pp. 552-563. Basic Books Inc., New York. (Repr. of 1925 ed. Hogarth Press, London.)

Gesell, A., and Thompson, H. (1938). The Psychology of Early Growth, p. 142. Macmillan. New York.

Goodhardt, J. F. (1902). The Diseases of Children, 7th ed., ed. G. F. Still, p. 479. Churchill, London.

Griffith, J. P. C. (1899). Nervous incontinence of faeces. Arch. Pediat., 16, 416.

Halliday, J. L. (1946). Epidemiology and the psychosomatic affections. A study in social medicine. Lancet, 2, 185.

Hartsilver, J. (1935). Incontinence of faeces in a young girl. ibid., 2. 427.

Henoch, E. H. (1889). Lectures on Children's Diseases, translated by J. Thomson from 4th German ed., vol. 2, p. 180 . New Sydenham Soc., London.

Holt. L. E. (1897). The Diseases of Infancy and Childhood, p. 407. Appleton, New York.

Hungerland, H. (1936). Chronische Obstipation als Ursache für Incontinentia alvi. Arch. Kinderheilk., 108, 43.

Huschka, M. (1942). The child's response to coercive bowel training. Psychosom. Med., 4, 301.

Isaacs. S. (1936). Habit. In On the Bringing $L_{p}^{+}$Of Children, ed. J. Rickman, pp. 123, 135, 147, 160, and 165. Kegan Paul, London.

Jekelius, E. (1936). Incontinentia alvi im Kindesalter. Arch. Kinderheilk., 109, 129.

Kanner, L. (1935). Child Psychiatry, pp. 224-227. Charles C. Thomas, Springfield, Illinois.

Lehman, E. (1944). Psychogenic incontinence of feces (encopresis) in children. Amer. J. Dis. Child., 68, 190.
MacFarlane, J. W., Allen, L, and Honzig. M. (1954). A Developmental Study of Behaviour Problems of Normal Children. Vol. 2, p. 85. University of California Publications in Child Development, Los Angeles.

MacGregor, M. (1961). Chronic constipation in children. In Psychosomatic Aspects of Paediatrics. ed. R. Mac Keith and J. Sandler (Study Group of Society for Psychosomatic Research, 1959), pp. 1-3. Pergamon Press, London.

Mac Keith. R. (1960). Faecal incontinence in children. Brit. med.J., 2. 1451 .

Mendenhall. W. ON. (1890). Neurotic incontinence of faeces. Medical Standard, 8, 126.

Nixon. H. H. (1961). In Discussion on megacolon and megarectum. Proc. roy. Soc. Med., 54. 1037.

Ostheimer, M. (1905). Incontinence of feces in children. Univ. Penn. med. Bull., 17, 405.

Pinkerton, P. (1958). Psychogenic megacolon in children: The implications of bowel negativism. Arch. Dis. Childh., 33. 371.

Priesel, R., and Siegl, J. (1936). Chronische Obstipation als Ursache für Incontinentia alvi. Arch. Kinderheilk., 107, 133.

Richmond, J. B., Eddy, E. J., and Garrard, S. D. (1954). The syndrome of fecal soiling and megacolon. Amer. J. Orthopsychiat., 24, 391.

Rivière, A. (1898). Incontinence fécale par regorgement chez une fillette de douze ans. Méd. mod., 9, 308.

Roberts, K. E.. and Schoellkopf, J. A. (1951). Eating, sleeping. and elimination practices of a group of 21 -year-old children. Amer. J. Dis. Child., 82, 121.

Rotch. T. M. (1901). Pediatrics, 3rd ed., p. 802. Lippincott, Philadelphia.

Schilling (1891). Unwillkürliche Stuhlentleerung der Jugend. Disch. MedZtg., 12. 691.

Shirky, H. F. (1938). Encopresis in children. $J$. Pediat, 12, 367. Smith, J. L. (1896). Treatise on the Medical and Surgical Diseases of Infancy and Childhood, 8th ed., p. 933. H. K. Lewis. London.

Thorling. I. (1923). Einige Typen von Incontentia alvi bei Kindern. Med. Rev. (Bergen), 40. 97.

Wallace, A. (1888). Incontinence of faeces for three years. St Bart. Hosp. Rep., 24, 260.

Weissenberg, S. (1926). Uber Enkopresis. Z. Kinderheilk., 40. 674.

Whiting, J. W. M. (1956). Discuss. Child Develop., 2, 189.

-, and Child, I. L. (1953). Child Training and Personality, pp. 73-77. Oxford University Press, London. 